\title{
PENENTUAN STATUS PEMANFAATAN DAN SKENARIO PENGELOLAAN IKAN CAKALANG (Katsuwonus pelamis) YANG TERTANGKAP DI PERAIRAN BOLAANG-MONGONDOW SULAWESI UTARA
}

\author{
John S. Kekenusa ${ }^{1)}$, Victor N.R. Watung ${ }^{2)}$, dan Djoni Hatidja ${ }^{1)}$ \\ ${ }^{1)}$ PS Matematika FMIPA UNSRAT, Manado \\ ${ }^{2)}$ PS Manajemen Sumberdaya Perikanan FPIK UNSRAT, Manado \\ e-mail: johnskekenusa@yahoo.com; vnrwatung@yahoo.com; dhatidja@gmail.com
}

\begin{abstract}
ABSTRAK
Ikan Cakalang (Katsuwonus pelamis L.), perlu dikelola dengan baik sebagai sumber daya alam terbarukan, tetapi semakin habis atau punah. Salah satu pendekatan dalam pengelolaan sumberdaya ikan adalah dengan pemodelan. Analisis dilakukan, bertujuan untuk mendapatkan model terbaik untuk model surplus produksi adalah Maximum Sustainable Yield (MSY), dan untuk mendapatkan pemanfaatan cakalang dan tingkat usaha. Data yang digunakan untuk model produksi surplus dikumpulkan dari data hasil tangkapan cakalang yang disediakan oleh Dinas Kelautan Dan Perikanan Kabupaten Bolaang Mongondow Provinsi Sulawesi Utara. Model terbaik Surplus Produksi dapat digunakan untuk menilai potensi hasil cakalang adalah model Fox. Upaya optimal per tahun secara biologi EMSY adalah 3.876 perjalanan. Hasil optimal secara biologi CMSY 1,505.00 ton per tahun. Tingkat pemanfaatan untuk tahun 2005 adalah 124,48\%, dengan tingkat usaha 110,96\%. Hasil tangkapan untuk tahun 2005 sudah di atas nilai MSY, yang menunjukkan overfishing
\end{abstract}

Kata kunci: ikan cakalang, Model surplus produksi, Maksimum Sustainable Yield, Bolaang Monogndow

\section{DETERMINATION OF THE STATUS OF UTILIZATION AND MANAGEMENT SCENARIOS SKIPJACK (Katsuwonus pelamis L.) CAUGHT IN THE BOLAANG MONGONDOW BEACH, NORTH SULAWESI}

\begin{abstract}
Skipjack (Katsuwonus pelamis L.), needs to be managed well as a renewable natural resources, but vunerable to depletion or extinction. One approach in fish resource management is by modeling. Analysis were carried out, aimed to get the best model for surplus production model, to assess the Maximum Sustainable Yield (MSY), and to get the skipjack utilization and effort level. Data used for surplus production model were collected from skipjack landings data provided by Marine and Fisheries Service (Dinas Kelautan dan Perikanan) of Bolaang-Mongondow Regency and North Sulawesi Province. The best Surplus Production Model that can be used to assess the skipjack potential yield is the Fox model. The optimum effort per year biologically $E_{\mathrm{MSY}}$ is 3,876 trips. The optimum yield biologically $\mathrm{C}_{\mathrm{MSY}}$ is $1,505.00$ tons per year. Utilization level for 2005 was $124.48 \%$, with effort level $110.96 \%$. The catch for 2005 had already above the MSY value, which shows an overfishing.
\end{abstract}

Keywords : Skipjack, Surplus Production Model, Maximum Sustainable Yield, Bolaang Mongondow

\section{PENDAHULUAN}

Ikan cakalang merupakan produk utama/unggulan di Sulawesi Utara, dan sebagai komoditi ekspor. Total produksi cakalang di Sulawesi Utara (termasuk perairan Bolaang-Mongondow untuk tahun 2010 mencapai 60.190,3 ton, dengan nilai milyaran rupiah (Anonim, 2011). Penelitian tentang ikan cakalang umumnya membahas tentang eksploitasi untuk meningkatkan produksi, belum banyak yang meneliti tentang status pemanfaatan (termasuk aspek kelestarian dan efisiensi) sumberdaya.

Penangkapan cakalang di perairan Bolaang-Mongondow telah berlangsung 
cukup lama, dengan intensitas yang padat. Data mengenai tingkat pemanfaatan suatu sumberdaya ikan sangat penting, karena akan menentukan apakah pemanfaatan sumberdaya tersebut kurang optimal, optimal, atau berlebih. Pemanfaatan sumberdaya ikan yang berlebihan akan mengancam kelestariannya. Dengan mengetahui tingkat pemanfaatan sumberdaya cakalang, diharapkan dapat dilakukan pengelolaan yang terencana dan lestari.

Model yang paling sederhana dalam dinamika populasi ikan ialah model produksi surplus, dengan memperlakukan ikan sebagai biomassa tunggal yang tak dapat dibagi, yang tunduk pada aturan-aturan sederhana kenaikan dan penurunan biomassa. Model ini, pada umumnya digunakan dalam penilaian stok ikan hanya dengan menggunakan data hasil tangkapan dan upaya tangkap yang umumnya tersedia.

Penelitian ini bertujuan untuk mendapatkan Model Produksi Surplus terbaik, serta mengetahui berapa besar hasil tangkapan maksimum lestari (MSY), tingkat pemanfaatan, dan tingkat pengusahaan ikan cakalang di perairan Bolaang-Mongondow.

\section{Tujuan dan Manfaat Penelitian}

Penelitian ini bertujuan untuk :

1. Mendapatkan model Model Produksi Surplus terbaik untuk diterapkan pada perikanan cakalang di perairan BolaangMongondow.

2. Mengetahui berapa besar hasil tangkapan maksimum lestari (MSY), tingkat pemanfaatan, dan tingkat pengusahaan ikan cakalang.

3. Menetapkan alokasi upaya-tangkap (jumlah trip kapal) yang paling menguntungkan untuk daerah penelitian.

Penelitian ini diharapkan bermanfaat dalam:

(1). Memberi informasi tentang batas maksimum jumlah ikan cakalang yang dapat ditangkap dan upaya-tangkap yang digunakan per tahun, agar sumberdaya ikan cakalang tetap lestari maupun yang paling menguntungkan secara ekonomi; dan (2) Memberi informasi tentang tingkat pemanfaatan dan pengusahaan perikanan cakalang di perairan Bolaang-Mongondow, apakah sudah terjadi tangkap-lebih (overfishing) atau tidak.

\section{TINJAUAN PUSTAKA}

\section{Model Produksi Surplus}

Model yang paling sederhana dalam dinamika populasi ikan ialah model produksi surplus yang memperlakukan populasi ikan sebagai biomassa tunggal yang tidak dapat dibagi, yang tunduk pada aturan-aturan sederhana dari kenaikan dan penurunannya. Model produksi ini tergantung pada 4 macam besaran, yaitu : biomassa populasi pada suatu waktu tertentu $t\left(B_{t}\right)$, tangkapan untuk suatu waktu tertentu $t\left(C_{t}\right)$, upaya tangkap pada waktu tertentu $t\left(E_{t}\right)$, dan laju pertumbuhan alami konstan (r) (Boer dan Aziz, 1995). Model ini pertama kali dikembangkan oleh Schaefer, yang bentuk awalnya sama dengan model pertumbuhan logistik.

Menurut Coppola dan Pascoe (1996), persamaan surplus produksi terdiri dari beberapa konstanta yang dipengaruhi oleh pertumbuhan alami, kemampuan alat tangkap, dan daya dukung lingkungan. Konstanta-konstanta tersebut diduga dengan menggunakan model-model penduga parameter biologi dari persamaan surplus produksi, yaitu model : Equilibrium Schaefer, Disequilibrium Schaefer, Schnute, dan Walter - Hilborn. Berdasarkan keempat model tersebut dipilih yang paling sesuai atau best fit dari pendugaan yang lain.

Menurut Sparre dan Venema (1999), rumus-rumus model produksi surplus hanya berlaku apabila parameter slope (b) bernilai negatif, yang berarti penambahan upaya tangkap akan menyebabkan penurunan hasil tangkapan per upaya tangkap. Apabila parameter $\mathrm{b}$ nilainya positip, maka tidak dapat dilakukan pendugaan besarnya stok maupun upaya optimum, tetapi hanya dapat disimpulkan bahwa penambahan upaya tangkap masih memungkinkan untuk meningkatkan hasil tangkapan.

Pendugaan upaya penangkapan optimum $\left(\mathrm{E}_{\mathrm{opt}}\right)$ dan hasil tangkapan maksimum lestari $\left(\mathrm{C}_{\mathrm{MSY}}\right)$ didekati dengan Model Produksi Surplus. Antara hasil tangkapan per satuan upaya $\left(\mathrm{CPUE}_{\mathrm{t}}\right)$ dan upaya tangkap (effort) dapat berupa hubungan linear maupun eksponensial (Gulland, 1983). Model Produksi Surplus terdiri dari 2 model dasar yaitu Model Schaefer (hubungan linear) dan Model Gompertz yang dikembangkan oleh Fox 
dengan bentuk hubungan eksponensial (Gulland, 1983).

\section{Model Schaefer}

Model produksi surplus pertama kali dikembangkan oleh Schaefer, yang bentuk awalnya sama dengan model pertumbuhan logistik. Model tersebut ialah sebagai berikut:

$$
\frac{d B_{t}}{d t}=\mathrm{G}\left(B_{t}\right)=\mathrm{rB}_{\mathrm{t}}\left(1-\frac{B_{t}}{K}\right)
$$

Persamaan ini belum memperhitungkan pengaruh penangkapan, sehingga Schaefer menuliskan kembali menjadi:

$\frac{d B_{t}}{d t}=\mathrm{rB}_{\mathrm{t}}\left(1-\frac{B_{t}}{K}\right)-\mathrm{C}_{\mathrm{t}}$

dengan $\mathrm{K}$ ialah daya dukung lingkungan perairan, dan $\mathrm{C}_{\mathrm{t}}$ ialah tangkapan yang dapat ditulis sebagai :

$\mathrm{C}_{\mathrm{t}}=\mathrm{q} \mathrm{E}_{\mathrm{t}} \mathrm{B}_{\mathrm{t}}$

dengan q sebagai koefisien ketertangkapan (catchability), dan $\mathrm{E}_{\mathrm{t}}$ menunjukkan upaya tangkap. Persamaan ini dapat ditulis menjadi:

$$
\frac{C_{t}}{E_{t}}=\mathrm{q} \mathrm{B}_{\mathrm{t}}=\text { CPUE }
$$

Dari persamaan diferensial (2), tangkapan optimum dapat dihitung pada saat $\frac{d B_{t}}{d t}=0$ atau disebut juga penyelesaian pada titik keseimbangan (equilibrium), yang berbentuk :

$\mathrm{rB}_{\mathrm{t}}\left(1-\frac{B_{t}}{K}\right)-\mathrm{C}_{\mathrm{t}}=0, \quad$ atau

$\mathrm{C}_{\mathrm{t}}=\mathrm{rB}_{\mathrm{t}}\left(1-\frac{B_{t}}{K}\right)=\mathrm{qE}_{\mathrm{t}} \mathrm{B}_{\mathrm{t}}$

Dari persamaan (3) dan (5) diperoleh nilai $\mathrm{B}_{\mathrm{t}}$ sebagai berikut :

$\mathrm{B}_{\mathrm{t}}=\mathrm{K}\left(1-\frac{q E_{t}}{r}\right)$

Sehingga persamaan (5) menjadi :

$$
\begin{aligned}
\mathrm{C}_{\mathrm{t}} & =\mathrm{q} \mathrm{KE}_{\mathrm{t}}\left(1-\frac{q E_{t}}{r}\right) \\
& =\mathrm{q} \mathrm{KE}_{\mathrm{t}}-\frac{q^{2} K}{r} \mathrm{E}_{\mathrm{t}}^{2}
\end{aligned}
$$

Persamaan (7) disederhanakan lagi oleh Schaefer menjadi :

$$
\begin{aligned}
\frac{C_{t}}{E_{t}} & =\mathrm{a}-\mathrm{b} \mathrm{E}_{\mathrm{t}}, \quad \text { atau } \\
\mathrm{C}_{\mathrm{t}} & =\mathrm{a} \mathrm{E}_{\mathrm{t}}-\mathrm{bE}_{\mathrm{t}}^{2}
\end{aligned}
$$

sedangkan $\mathrm{a}=\mathrm{q} \mathrm{K}$ dan $\mathrm{b}=\frac{q^{2} K}{r}$. Hubungan linear ini yang digunakan secara luas untuk menghitung $\mathrm{C}_{\mathrm{MSY}}$ melalui penentuan turunan pertama $\mathrm{C}_{\mathrm{t}}$ terhadap $\mathrm{E}_{\mathrm{t}}$ untuk mencari solusi optimal, baik untuk tangkapan maupun upaya tangkap. Turunan pertama $\mathrm{C}_{\mathrm{t}}$ terhadap $\mathrm{E}_{\mathrm{t}}$ adalah:

$$
\frac{d C_{t}}{d E_{t}}=\mathrm{a}-2 \mathrm{~b} \mathrm{E}_{\mathrm{t}} \text {, sehingga diperoleh }
$$

dugaan $\mathrm{E}_{\text {opt }}$ (upaya tangkap optimum) dan $\mathrm{C}_{\mathrm{MSY}}$ (tangkapan maksimum lestari) masingmasing :

$$
\mathrm{E}_{\mathrm{opt}}=\frac{a}{2 b}=\frac{r}{2 q}
$$

dengan memasukkan nilai $\mathrm{E}_{\mathrm{opt}}$ pada persamaan (8), akan diperoleh $\mathrm{C}_{\mathrm{MSY}}$ sebagai berikut :

$\mathrm{C}_{\mathrm{MSY}}=\mathrm{a} \mathrm{E}_{\mathrm{t}}-\mathrm{bE}_{\mathrm{t}}^{2}$

$=\mathrm{a}\left(\frac{a}{2 b}\right)-\mathrm{b}\left(\frac{a}{2 b}\right)^{2}=\frac{a^{2}}{4 b}$

dengan mensubstitusi $\mathrm{a}=\mathrm{qK}$ dan $\mathrm{b}=\frac{q^{2} K}{r}$, akan diperoleh

$$
\mathrm{C}_{\mathrm{MSY}}=\frac{a^{2}}{4 b}=\frac{q^{2} K^{2}}{4 q^{2} K / r}=\frac{r K}{4}
$$

Nilai-nilai $a$ dan $b$ diduga melalui pendekatan metode kuadrat terkecil yang umum digunakan untuk menduga koefisien persamaan regresi sederhana. Selanjutnya, dengan memasukkan nilai $\mathrm{E}_{\mathrm{opt}}$ pada persamaan (6) diperoleh biomassa optimum ( $\mathrm{B}_{\mathrm{MSY}}$ ) sebagai berikut :

$$
\begin{aligned}
\mathrm{B}_{\mathrm{MSY}} & =\mathrm{K}-\frac{K q}{r} E_{o p t} \\
& =\mathrm{K}-\frac{K q}{r}\left(\frac{r}{2 q}\right)=\mathrm{K}-\frac{K}{2} \\
& =\frac{K}{2}
\end{aligned}
$$

Nilai-nilai parameter $\mathrm{q}, \mathrm{K}$, dan $\mathrm{r}$ dapat dihitung dengan menggunakan algoritma Fox, seperti yang diacu dalam Sularso (2005), sebagai berikut :

$\mathrm{q}_{\mathrm{t}}=\ln \left[\left|\left(z U_{t}^{-1}+\frac{1}{b}\right) /\left(z U_{t+1}^{-1}+\frac{1}{b}\right)\right|\right] /(z)$

dimana $\mathrm{z}=-(\mathrm{a} / \mathrm{b}) / \mathrm{E}^{*}, \quad \mathrm{E}^{*}=\left(\mathrm{E}_{\mathrm{t}}+\mathrm{E}_{\mathrm{t}+1}\right) / 2$, $U_{t}=\frac{C_{t}}{E_{t}}$, dan nilai $\mathrm{q}$ adalah rata-rata 
geometrik dari nilai $\mathrm{q}_{\mathrm{t}}$. Dari nilai $\mathrm{a}, \mathrm{b}$, dan $\mathrm{q}$, selanjutnya dapat dihitung nilai $\mathrm{K}$ dan $\mathrm{r}$.

\section{Model Fox}

Model Fox (1970) memiliki beberapa karakteristik yang berbeda dari model Schaefer, yaitu pertumbuhan biomassa mengikuti model pertumbuhan Gompertz. Penurunan CPUE terhadap upaya tangkap (E) mengikuti pola eksponensial negatif.

$\mathrm{C}_{\mathrm{t}}=\mathrm{E}_{\mathrm{t}} \cdot \exp \left(\mathrm{a}-\mathrm{b} \mathrm{E}_{\mathrm{t}}\right)$ menyamakan turunan pertama $C_{t}$ terhadap $E_{t}$ sama dengan nol.

$\mathrm{E}_{\mathrm{opt}}=\frac{1}{b}$

Hasil tangkapan maksimum lestari $\left(\mathrm{C}_{\mathrm{MSY}}\right)$ didapat dengan memasukkan nilai upaya optimum ke dalam persamaan (13), dan diperoleh :

$\mathrm{C}_{\mathrm{MSY}}=\frac{1}{b} \mathrm{e}^{\mathrm{a}-1}$

\section{Model Schnute}

Schnute (1977), mengemukakan versi lain dari model produksi surplus yang bersifat dinamis serta deterministik. Metode Schnute dianggap sebagai modifikasi dari model Schaefer dalam bentuk diskret (Roff, 1983, yang diacu dalam Tinungki 2005).

$\ln \left(\frac{U_{t+1}}{U_{t}}\right)=\mathrm{r}-\frac{r}{q K}\left(\frac{U_{t}+U_{t+1}}{2}\right)-$

$\mathrm{q}\left(\frac{E_{t}+E_{t+1}}{2}\right)=\mathrm{a}-\mathrm{b}\left(\frac{U_{t}+U_{t+1}}{2}\right)-$

$\mathrm{c}\left(\frac{E_{t}+E_{t+1}}{2}\right)$

dimana $\mathrm{a}=\mathrm{r}, \mathrm{b}=\frac{r}{q K}$, dan $\mathrm{c}=\mathrm{q}$, adalah penduga parameter koefisien regresi berganda.

\section{Model Walter - Hilborn}

Walter dan Hilborn (1976) yang
diacu dalam Tinungki (2005), mengembangkan jenis lain dari model produksi surplus, yang dikenal sebagai model regresi. Model Walter - Hilborn ini, menggunakan persamaan diferensial sederhana,dengan persamaan sebagai berikut:

$$
\begin{aligned}
\frac{U_{t+1}}{U_{t}}-1 & =\mathrm{r}-\frac{r}{K q} \mathrm{U}_{\mathrm{t}}-\mathrm{qE}_{\mathrm{t}} \\
& =\mathrm{a}-\mathrm{b} \mathrm{U}_{\mathrm{t}}-\mathrm{c} \mathrm{E}_{\mathrm{t}}
\end{aligned}
$$

dimana $\mathrm{a}=\mathrm{r}, \mathrm{b}=\frac{r}{K q}$, dan $\mathrm{c}=\mathrm{q}$, adalah penduga parameter koefisien regresi berganda.

\section{Model Clarke Yoshimoto Pooley (CYP)}

Pendugaan parameter biologi untuk model produksi surplus dapat pula dilakukan melalui teknik pendugaan yang dikemukakan oleh Clarke, Yoshimoto, dan Pooley (Fauzi dan Anna 2005, Tinungki 2005). Parameterparameter yang diduga ialah $\mathrm{r}, \mathrm{K}$, dan $\mathrm{q}$, dengan model yang dinyatakan sebagai berikut :

$\ln \left(U_{t+1}\right)=\left(\frac{2 r}{2+r}\right) \ln (q K)+\frac{2-r}{2+r} \ln \left(U_{t}\right)-\frac{q}{2+r}\left(E_{t}+E_{t+1}\right)$

di mana : $\quad a^{\prime}=\frac{2 r}{2+r}, \quad a=a^{\prime} \ln (q K)$, $b=\frac{2-r}{2+r}, \quad c=\frac{q}{2+r}$ dengan demikian persamaan (18) dapat ditulis dalam bentuk :

$$
\begin{aligned}
& \ln \left(U_{t+1}\right)=a^{\prime} \ln (q K)+b \ln \left(U_{t}\right)-c\left(E_{t}+E_{t+1}\right) \\
& =a+b \ln \left(U_{t}\right)-c\left(E_{t}+E_{t+1}\right)
\end{aligned}
$$

\section{METODE PENELITIAN}

\section{Sumber Data}

Data yang dikumpulkan ialah data sekunder tentang hasil tangkapan ikan cakalang di perairan Bolaang-Mongondow dan sekitarnya. Data produksi dan upaya tangkap dikumpul dari Dinas Kelautan dan Perikanan Kabupaten Bolaang-Mongondow dan Provinsi Sulawesi Utara selama tahun $1991-2010$.

Data (variabel) yang digunakan untuk analisis model produksi surplus ialah data hasil tangkapan $\left(\mathrm{C}_{\mathrm{t}}\right)$ per tahun dan upaya tangkap $\left(\mathrm{E}_{\mathrm{t}}\right)$ per tahun, serta $\operatorname{CPUE}\left(\frac{C_{t}}{E_{t}}\right)$.

Data (variabel) yang digunakan untuk analisis model produksi surplus ialah sebagai berikut

1. Hasil tangkapan $\left(\mathrm{C}_{\mathrm{t}}\right)$ : berat ikan yang didaratkan (ton) pada tahun ke $\mathrm{t}$

2. Upaya tangkap $\left(E_{t}\right)$ : jumlah kapal motor penangkap ikan yang mendaratkan 
hasilnya di tempat pendaratan (trip) pada tahun ke $\mathrm{t}$

3. $\frac{C_{t}}{E_{t}}: \quad \mathrm{C}_{\mathrm{t}}$ dibagi $\mathrm{E}_{\mathrm{t}}$ (ton /trip) pada tahun ke $\mathrm{t}$

\section{Metode Analisis Data}

Model penduga yang dianalisis dan dievaluasi ialah : model Schaefer, model Fox, model Schnute, model Walter-Hilborn, dan model Clarke Yoshimoto Pooley (CYP). Berdasarkan hasil evaluasi secara statistika, akan diperoleh suatu model yang "terbaik" sebagai penduga. Dari model terbaik tersebut dapat dihitung nilai $\mathrm{C}_{\mathrm{MSY}}$, upaya tangkap optimum, tingkat pemanfaatan, dan tingkat pengusahaan sumberdaya perikanan cakalang.

\section{HASIL DAN PEMBAHASAN}

Hasil tangkapan perikanan cakalang di perairan Bolaang-Mongondow dari tahun ke tahun walaupun berfluktuasi tetapi cenderung meningkat. Data hasil tangkapan selang tahun 1991-2010, diringkas dalam Tabel 1.

Tabel 1 Jumlah Hasil Tangkapan, upaya tangkap, dan CPUE ikan cakalang di perairan Bolaang-Mongondow tahun 1991-2010

\begin{tabular}{|c|c|c|c|}
\hline Tahun & $\begin{array}{c}\text { Tangkapan } \\
\text { (ton) }\end{array}$ & $\begin{array}{c}\text { Upaya } \\
\text { (trip) }\end{array}$ & $\begin{array}{c}\text { CPUE } \\
\text { (ton/trip }\end{array}$ \\
\hline 1991 & 698,2 & 2.455 & 0,2844 \\
\hline 1992 & 826,0 & 8.650 & 0,0955 \\
\hline 1993 & 866,2 & 6.195 & 0,1398 \\
\hline 1994 & 901,6 & 5.347 & 0,1686 \\
\hline 1995 & 875,4 & 6.272 & 0,1396 \\
\hline 1996 & 763,9 & 8.560 & 0,0892 \\
\hline 1997 & 899,6 & 9.948 & 0,0904 \\
\hline 1998 & $1.218,3$ & 9.950 & 0,1224 \\
\hline 1999 & $1.268,4$ & 4.037 & 0,3142 \\
\hline 2000 & 1250,3 & 3.027 & 0,4130 \\
\hline 2001 & $1.304,3$ & 1.102 & 1,1836 \\
\hline 2002 & $1.461,3$ & 3.366 & 0,4341 \\
\hline 2003 & $2.137,1$ & 4.368 & 0,4893 \\
\hline 2004 & $1.995,7$ & 6.464 & 0,3087 \\
\hline 2005 & $1.873,4$ & 4.301 & 0,4356 \\
\hline 2006 & $1.203,7$ & 1.020 & 1,1801 \\
\hline 2007 & $1.246,9$ & 7.544 & 0,1653 \\
\hline 2008 & $1.369,0$ & 6.410 & 0,2136 \\
\hline 2009 & $1.379,0$ & 6.400 & 0,2155 \\
\hline 2010 & $1.631,0$ & 6.452 & 0,2528 \\
\hline Rata-rata & $\mathbf{1 . 2 5 8 , 4 6 5}$ & $\mathbf{5 . 5 9 3 , 4 0}$ & $\mathbf{0 , 3 3 6 8}$ \\
\hline
\end{tabular}

Sumber : Diolah dari data Dinas Kelautan dan Perikanan Kabupaten Bolaang- Mongondow Provinsi Sulawesi Utara

\section{Model Schaefer}

Dari hasil analisis diperoleh persamaan regresi $\frac{C_{t}}{E_{t}}=\mathbf{0 , 8 6 8}-\mathbf{0 , 0 0 0 0 9 4 9}$
$\mathbf{E}_{\mathbf{t}}$, dengan nilai koefisien determinasi $\left(\mathrm{R}^{2}\right)=$ 0,632 dan tingkat signifikansi $\mathrm{p}<0,001$. Dengan demikian model produksi penduga hasil tangkapan untuk model Schaefer sesuai 
persamaan (8) ialah : $\quad \mathbf{C}_{\mathbf{t}}=\mathbf{0 , 8 8 6} \quad \mathbf{E}_{\mathbf{t}}-$ $0,0000949 \mathrm{E}_{\mathrm{t}}^{2}$.

\section{Model Fox}

Dari hasil analisis regresi diperoleh persamaan regresi :

$\operatorname{Ln} \frac{C_{t}}{E_{t}}=\mathbf{0 , 0 5 4}-\mathbf{0 , 0 0 0 2 5 8} \mathrm{E}_{\mathbf{t}}, 58$ dengan $\mathrm{R}^{2}$ $=0,808(\mathrm{p}<0,001)$. Penduga hasil tangkapan untuk model Fox sesuai persamaan (13) ialah: $C_{t}=E_{t} \cdot \mathbf{e}^{(0,054-0,000258 \mathrm{Et})}$.

\section{Model Schnute}

Untuk metode Schnute diperoleh persamaan regresi $\operatorname{Ln}\left(\mathbf{U}_{\mathbf{t}+\mathbf{1}} / \mathbf{U}_{\mathbf{t}}\right)=\mathbf{0 , 9 6 9}-$ $1,121\left(U_{t+1}+U_{t}\right) / 2-0,00009201\left(E_{t+1}+E_{t}\right) / 2$ dengan $\mathrm{R}^{2}=0,034$, dan semua koefisen regresi tidak ada yang signifikan $(\mathrm{p}>0,05)$.

\author{
Model Walter - Hilborn \\ Pada metode Walter-Hilborn \\ diperoleh persamaan regresi $\left(\mathbf{U}_{t+1} / \mathbf{U}_{t}\right)-\mathbf{1}=$ \\ $0,160-0,525 U_{t}+0,00004725 E_{t}$ dengan $R^{2}$ \\ $=0,135$, dengan semua variabel tidak \\ signifikan $(\mathrm{p}>0,05)$.
}

\section{Model Clarke Yoshimoto Pooley (CYP) \\ Pada metode CYP diperoleh} persamaan regresi $\operatorname{Ln}\left(\mathbf{U}_{t+1}\right)=\mathbf{0 , 2 6 5}-\mathbf{0 , 3 5 7}$ $\ln \left(\mathbf{U}_{\mathrm{t}}\right)-\mathbf{0 , 0 0 0 1 9 2}\left(\mathbf{E}_{\mathrm{t}}+\mathbf{E}_{\mathrm{t}+1}\right)$ dengan $\mathrm{R}^{2}=$ 0,648 , dan tidak semua koefisen regresi signifikan.

\section{PEMBAHASAN}

Hasil perhitungan dan analisis untuk kelima model produksdi surplus, disajikan pada Tabel 2 .

Tabel 2. Hasil perhitungan dan validasi model produksi surplus

\begin{tabular}{|l|l|c|c|c|c|}
\hline & $\begin{array}{c}\text { Model } \\
\text { Schaefer }\end{array}$ & $\begin{array}{c}\text { Model } \\
\text { Fox }\end{array}$ & $\begin{array}{c}\text { Model } \\
\text { Schnute }\end{array}$ & $\begin{array}{c}\text { Model } \\
\text { Walter- } \\
\text { Hilborn }\end{array}$ & Model CYP \\
\hline $\begin{array}{l}\text { Kesesuaian } \\
\text { Tanda }\end{array}$ & Sesuai & Sesuai & Sesuai & $\begin{array}{c}\text { Tidak } \\
\text { Sesuai }\end{array}$ & Tidak Sesuai \\
\hline Nilai $\mathrm{R}^{2}$ & 0,632 & $\mathbf{0 , 8 0 8}$ & 0,034 & 0,135 & 0,648 \\
\hline $\begin{array}{l}\text { Nilai } \\
\text { Validasi }\end{array}$ & 0,5706 & $\mathbf{0 , 2 8 9 3}$ & 0,6462 & 2,6428 & 1,0292 \\
\hline $\begin{array}{l}\text { Signifikansi } \\
\text { Koefisien } \\
\text { Regresi } \\
\text { Individu }\end{array}$ & Signifikan & Signifikan & $\begin{array}{c}\text { Tidak } \\
\text { Signifikan }\end{array}$ & $\begin{array}{c}\text { Tidak } \\
\text { Signifikan }\end{array}$ & $\begin{array}{c}\text { Tidak } \\
\text { Signifikan }\end{array}$ \\
\hline
\end{tabular}

Dari hasil perhitungan pada Tabel 2, terlihat bahwa yang paling sesuai ialah model Fox dengan nilai $\mathrm{R}^{2}$ cukup besar $\left(\mathrm{R}^{2}=0,808\right)$ dan validasi (nilai residual) paling kecil. Dari model Fox diperoleh nilai a $=0,054$ dan nilai $\mathrm{b}=0,000258$, dengan persamaan (14) dan (15 dapat dihitung nilai Upaya optimum $\left(\mathrm{E}_{\mathrm{opt}}\right)$ dan Tangkapan maksimum lestari $\left(\mathrm{C}_{\mathrm{MSY}}\right)$ sebagai berikut :

$\mathrm{E}_{\text {opt }}=\frac{1}{b}=\frac{1}{0,000258}=3875,969 \approx 3876$ trip/tahun.

$$
\begin{aligned}
\mathrm{C}_{\text {MSY }} & =\frac{1}{b} \mathrm{e}^{\mathrm{a}-1}=\frac{1}{0,000258} \mathrm{e}^{0,054-1} \\
& =1505,00 \text { ton/tahun. }
\end{aligned}
$$

Ini berarti bahwa untuk menjaga kelestarian sumberdaya perikanan cakalang secara teknis dan biologis, dalam setahun jumlah unit penangkapan tidak boleh melebihi 3876 trip. Untuk menjaga kelestarian sumberdaya ikan cakalang di perairan Bolaang-Mongondow, maksimum ikan yang dapat ditangkap sebesar 1505,00 ton/tahun.

Selanjutnya dari nilai $\mathrm{E}_{\mathrm{opt}}$ dan $\mathrm{C}_{\mathrm{MSY}}$ dapat dihitung tingkat upaya penangkapan dan tingkat pemanfaatan ikan cakalang untuk tahun tertentu misalkan tahun 2005, sebagai berikut :

Tingkat upaya tahun $2005=\frac{E_{2005}}{E_{o p t}} \times 100 \%$

$=\frac{4301}{3876} \times 100 \%=110,96 \%$

Tingkat pemanfaatan tahun 2005

$=\frac{C_{2005}}{C_{M S Y}} \times 100 \%$ 
$=\frac{1873,4}{1505,00} \times 100 \%=124,48 \%$.

Dari hasil perhitungan, ternyata upaya tangkap ikan cakalang di perairan BolaangMongondow pada tahun 2005 sudah melebihi tingkat upaya maksimum lestari, demikian pula tingkat pemanfaatannya sudah melebihi $100 \%$. Hal ini menunjukkan bahwa untuk tahun 2005 hasil tangkapan sudah melampaui batas tangkapan maksimum lestari atau terjadi overfishing (tangkap lebih).

Penelitian ini menjelaskan penggunaan beberapa kriteria statistika dalam memilih model produksi surplus terbaik. Dengan menerapkan beberapa kriteria statistika dalam memilih model produksi surplus, akan diperoleh hasil yang lebih baik. Para peneliti di bidang perikanan mendapatkan pedoman dalam menetapkan kriteria pemilihan model produksi surplus, sekaligus juga menghindari penerapan langsung satu model saja dalam menganalisis model produksi surplus di suatu perairan.

Karena adanya indikasi terjadi overfishing (tangkap lebih), disarankan agar pemerintah menerapkan peraturan mengenai pembatasan ukuran ikan cakalang yang akan ditangkap. Peraturan tersebut harus diawasi pelaksanaannya melalui sistem monitoring, controlling, dan surveillance (MCS) yang tegas. Selain itu, untuk mencegah tingkat pemanfaatan yang mengganggu kelestarian stok, perlu dilakukan pengaturan zonasi penangkapan melalui alokasi penggunaan rumpon yang menjadi daerah penangkapan ikan cakalang.

\section{KESIMPULAN DAN SARAN}

\section{Kesimpulan}

1. Model Produksi Surplus yang dapat digunakan untuk menelaah hasil tangkapan ikan cakalang di perairan Bolaang-Mongondow ialah Model Fox, dengan persamaan : $\mathbf{C}_{\mathbf{t}}=\mathbf{E}_{\mathbf{t}} \cdot \mathbf{e}^{(\mathbf{0}, 054-}$ 0,000258 Et)

2. Hasil tangkapan maksimum lestari ikan cakalang $\mathrm{C}_{\mathrm{MSY}}$ sebesar 1505,00 ton per tahun, diperoleh pada tingkat upaya tangkap $\mathrm{E}_{\mathrm{MSY}} 3876$ trip. Untuk tahun 2005 besarnya tingkat pemanfaatan sebesar 124,48 \% dan ini tergolong overfishing (tangkap-lebih), dengan tingkat pengupayaan sebesar $110,96 \%$ juga sudah melampaui batas nilai optimum.

\section{Saran}

1. Dalam menerapkan model produksi surplus di suatu perairan, tidak hanya langsung menggunakan satu model tertentu saja, tetapi hendaknya menggunakan beberapa model yang dipilih berdasarkan kriteria statistika. Kriteria tersebut menyangkut antara lain : kesesuaian tanda, nilai koefisien determinasi $\left(\mathrm{R}^{2}\right)$, nilai validasi, dan signifikansi koefisien regresi.

2. Karena ada indikasi terjadi overfishing (tangkap lebih) dan besarnya intensitas upaya penangkapan cakalang di perairan Bolaang-Mongondow, disarankan secepatnya dilakukan pengawasan oleh pihak berkompeten untuk menangani masalah ini. Terutama melakukan efisiensi terhadap upaya tangkap.

3. Perlu adanya perbaikan sistem penyajian dan pengumpulan data perikanan yang dilakukan pemerintah, agar tersedia data yang sesuai untuk kebutuhan analisis pengelolaan sumberdaya. Sebagai contoh, untuk data upaya tangkap (effort) tidak hanya dicatat nilai nominalnya (jumlah kapal, jumlah alat, dan lain-lain), akan tetapi yang lebih penting lagi ialah nilai efektifnya. Misalnya jumlah hari-kapal (boat-day) yaitu jumlah kapal dikali jumlah hari operasi. Data seperti ini lebih dapat menggambarkan efektifitas upaya tangkap, dibanding dengan hanya jumlah kapal atau jumlah alat tangkap yang digunakan yang belum tentu semuanya efektif.

\section{DAFTAR PUSTAKA}

Anonim. 2011. Buku Tahunan Statistik Perikanan Tangkap Sulawesi Utara Tahun 2010. Manado.

Aziz, K. A. 1989. Pendugaan Stok Populasi Ikan Ikan Tropis. Bahan Pengajaran (Tidak Dipublikasi). Pusat Antar Universitas Ilmu Hayat, Institut Pertanian Bogor, Bogor. 89 hal. 
Aziz, K.A. dan B. Wahyudi. 1997. Sistem Pemantauan dan Basis Data Pengkajian Stok. Makalah dalam Potensi dan Penyebaran Sumberdaya Ikan Laut di Perairan Indonesia. Proyek Pengembangan dan Pemanfaatan Sumberdaya Perikanan Laut Direktorat Jenderal Perikanan, Departemen Pertanian, Jakarta. Halaman 13 - 32.

Boer, M., dan K.A. Azis. 1995. Prinsipprinsip Dasar Pengelolaan Sumberdaya Perikanan Melalui Pendekatan BioEkonomi. Jurnal Ilmu-ilmu Perairan dan Perikanan: 3(2):109-119.

Boer, M., K.A. Azis, J. Widodo, A. Djamali, A. Ghofar, dan R. Kurnia. 2001. Potensi, Pemanfaatan dan Peluang Pengembangan Sumberdaya Ikan Laut di Perairan Indonesia. Pusat Kajian Sumberdaya Pesisir dan Lautan, Institut Pertanian Bogor.

Coppola G., and S. Pascoe. 1996. A Surplus Production Model with a non-linear Catch-Effort Relationship. (Research Paper 105) Center for the Economics and Managemant of Aquatic Resources University of Portsmouth.

FAO. 1994. Review of the State of World Marine Fisheries Resources. FAO Fisheries Technical Paper. Rome. 136 p.

Fauzi, A. 2002. A Note Surplus Production Model. IPB, Darmaga Bogor.

Fauzi, A., dan S. Anna. 2005. Pemodelan Sumberdaya Perikanan dan Kelautan untuk Analisis Kebijakan. PT. Gramedia Pustaka Utama, Jakarta.

Fox, W.W. 1970. An Exponential Surplus Yield Model for Optimazing Exploited Fish Population. Trans. Am. Fish Soc. 99(1):80-88.

Gafa, B., I.G.S. Merta, H.R. Barus, dan E.M. Amin. 1993. Penurunan Hasil Tangkapan Ikan Tuna dan Cakalang di Perairan Sulawesi Utara dan Faktorfaktor yang Mempengaruhinya. Jur. Pen. Perikanan Laut 72 : $11-19$.

Gulland, J.A. 1983. Fishing and Stock of Fish at Iceland. Mui.'Agric. Fish Food, Invest. (Ser.2) 23(4): $52-70$.
Kekenusa, J.S. 2006. Pemodelan Hasil Tangkapan dan Evaluasi Model Produksi Surplus Ikan Cakalang yang Tertangkap di Perairan Sekitar Bitung Provinsi Sulawesi Utara. Disertasi (Tidak Dipublikasikan). Program Pascasarjana Universitas Airlangga. Surabaya. 140 hal.

Kekenusa, J.S. 2007. Analisis Bio-ekonomi Ikan Cakalang yang Tertangkap di Perairan Sekitar Bitung Provinsi Sulawesi Utara. Pacific Journal Vol.2 No.1 :71-76.

Kekenusa, J.S., V.N.R. Watung, Dj. Hatidja, dan A.J. Rindengan. 2008. Penentuan Status Pemanfaatan dan Skenario Pengelolaan Ikan Cakalang (Katsuwonus pelamis) yang Tertangkap di Perairan Sulawesi Utara. Laporan Penelitian Hibah Bersaing.

Kekenusa, J.S., V.N.R. Watung, dan Dj. Hatidja. 2009. Penentuan Status Pemanfaatan dan Skenario Pengelolaan Ikan Cakalang (Katsuwonus pelamis) yang Tertangkap di Perairan SangiheTalaud. Laporan Kegiatan Penelitian Strategis Nasional Tahun 2009.

Kusnawan, I. 1999. Analisis Tingkat Pengusahaan dan Musim Penangkapan Ikan Cakalang (Katsuwonus pelamis) dengan Pendekatan Hasil Tangkapan yang Didaratkan di Pelabuhan Perikanan Pelabuhan Ratu. Skripsi (Tidak Dipublikasikan). Program Studi Ilmu Kelautan, Fakultas Perikanan dan Ilmu Kelautan Institut Pertanian Bogor. Bogor. 77 hal.

Menard, F., A. Fonteneau, D. Gaertner, V. Nordstrom, B. Stequert, and E. Marchal. 2000. Exploitation of Small Tunas by a Purse-Seine Fishery With Fish Aggregating devices and Their Feeding Ecology in an Eastern Tropical Atlantic Ecosystem. ICES Journal of Marine Science 57:525-530.

Meyer, W.J. 1987. Concepts of Mathematical Modelling. McGrawHill Inc. New York. 439p.

Monintja, D. R., dan R. Yusfiandayani. 1999. Teknologi Penangkapan Ikan Cakalang dan Tuna. Laboratorium Teknologi Penangkapan Ikan, FPIKIPB. Bogor. 27 hal. 
Monintja, D. R., dan R. Yusfiandayani. 2001. Pemanfaatan Sumberdaya Pesisir Dalam Bidang Perikanan Tangkap. Prosiding Pelatihan Pengelolaan Wilayah Pesisir Terpadu. IPB, Bogor.

Monintja, D. R., dan Zulkarnain. 1995. Analisis Dampak Pengoperasian Rumpon Tipe Philipine di Perairan ZEE terhadap Perikanan Cakalang di Perairan Teritorian Selatan Jawa dan Utara Sulawesi. Laporan Penelitian. Fakultas Perikanan Institut Pertanian Bogor. Bogor. 70 hal.

Purwanto. 1988. Bio-Ekonomi Penangkapan Ikan : Model Statik. Oseana. Vol. XIII No. 2. Departemen Pertanian, Jakarta.

Schnute, J. 1977. Improved Estimates from the Schaefer Production Models : Theoretical Considerations: J. Fish. Res. Board Can., 34:583-663.

Sparre , P. and S.C. Venema. 1999. Introduksi Pengkajian Stok Ikan Tropis. Buku 1 Manual. (Terjemahan J. Widodo. I.G.S. Merta, S. Nurhakim, dan M. Badrudin). Pusat Penelitian dan Pengembangan Perikanan, Badan Penelitian dan Pengembangan Pertanian (Kerjasama dengan Organisasi Pangan dan Pertanian Perserikatan Bangsa-bangsa). Jakarta. 438 hal.

Suharman, I. 1981. Suatu Penelitian Tentang Penangkapan Skipjack dengan Purse Seine di Perairan Utara Irian Jaya. Karya Ilmiah, Fakultas Perikanan Institut Pertanian Bogor, Bogor.

Sularso, A. 2005. Alternatif Pengelolaan Perikanan Udang di Laut Arafura. Disertasi (Tidak Dipublikasikan). Sekolah Pascasarjana Institut Pertanian Bogor. Bogor. 130 hal.

Tinungki, G. M. 2005. Evaluasi Model Produksi Surplus dalam Menduga Hasil Tangkapan Maksimum Lestari untuk Menunjang Pengelolaan Perikanan Lemuru Di Selat Bali. Disertasi (Tidak Dipublikasikan). Sekolah Pascasarjana Institut Pertanian Bogor. Bogor. 207 hal.
Uktolseja, J.C.B. 1997. Laporan Penelitian Indeks Kelimpahan Ikan Tuna dan Cakalang di Sekitar Rumpon (Tidak Diterbitkan). Balai Penelitian Perikanan Laut, Jakarta. 29 hal.

Uktolseja, J.C.B, B. Gafa, R. Purwasasmita, dan B. Iskandar. 1997. Sumberdaya Ikan Pelagis Besar. Makalah dalam Potensi dan Penyebaran Sumberdaya Ikan Laut di Perairan Indonesia. Proyek Pengembangan dan Pemanfaatan Sumberdaya Perikanan Laut Direktorat Jenderal Perikanan Laut, Departemen Pertanian, Jakarta. Halaman 33 - 54.

Uktolseja, J.C.B, R. Purwasasmita, K. Susanto, dan A.B. Sulistiadji. 1998. Sumberdaya Ikan Pelagis Besar. Makalah dalam Potensi dan Penyebaran Sumberdaya Ikan Laut di Perairan Indonesia. Komisi Nasional Pengkajian Stok Sumberdaya Ikan Laut LIPI, Jakarta. Halaman $40-88$.

Wahyono, U. 1999. Potensi Perikanan Indonesia. Makalah dalam Prosiding Seminar Validasi Data Inderaja untuk Bidang Perikanan 14 April 1999 di Jakarta. BPPT Jakarta, hal. 18-32.

Widodo, J. 1987. Modified Surplus Production Methods of Gulland (1961), and Schnute (1977). A Serial Seminars Published by Oceana XII(2):119-130.

Zar, J.H. 1984. Biostatistical Analysis. Prentice-Hall, New Jersey. 